\title{
Editorial
}

\section{Calcium signaling in physiology and pathophysiology}

\author{
He-ping CHENG $^{1,4}$, Sheng WEI ${ }^{1}$, Li-ping $\mathrm{WEI}^{2}$, Alexei VERKHRATSKY ${ }^{3,4}$ \\ ${ }^{1}$ Institute of Molecular Medicine and State Key Laboratory of Biomembrane and Membrane Biotechnology, College of Life Science, \\ Peking University, Beijing 100871, China $;^{2}$ Center for Bioinformatics, College of Life Science, Peking University, Beijing 100871, China; \\ ${ }^{3}$ Faculty of Life Sciences, the University of Manchester, Manchester M13 9PT, UK
}

\author{
${ }^{4}$ Correspondence to Prof He-ping CHENG. \\ Phn/Fax 86-10-6276-5957. \\ E-mail chengp@pku.edu.cn \\ and Prof Alexei VERKHRATSKY. \\ Phn 44-161-275-5414. \\ Fax 44-161-275-5948. \\ E-mail alex.verkhratsky@manchester.ac.uk
}

Received 2006-05-22

Accepted 2006-05-22

doi: $10.1111 /$ j.1745-7254.2006.00399.x

\begin{abstract}
Calcium ions are the most ubiquitous and pluripotent cellular signaling molecules that control a wide variety of cellular processes. The calcium signaling system is represented by a relatively limited number of highly conserved transporters and channels, which execute $\mathrm{Ca}^{2+}$ movements across biological membranes and by many thousands of $\mathrm{Ca}^{2+}$-sensitive effectors. Molecular cascades, responsible for the generation of calcium signals, are tightly controlled by $\mathrm{Ca}^{2+}$ ions themselves and by genetic factors, which tune the expression of different $\mathrm{Ca}^{2+}$-handling molecules according to adaptational requirements. $\mathrm{Ca}^{2+}$ ions determine normal physiological reactions and the development of many pathological processes.
\end{abstract}

Ja, Kalzium das ist alles...

Otto Loewi

(1936 Nobel Laureate)

Experimental indications, demonstrating the role of calcium as a universal signalling molecule, controlling a huge variety of very different physiological functions appeared at the end of 19th century. First, Sydney Ringer showed that calcium ions were indispensable for fish survival, muscle contraction, the development of fertilized eggs and tadpole and for cells adhesion ${ }^{[1-5]}$. Several years later, Locke ${ }^{[6]}$ and Overton ${ }^{[7]}$ demonstrated the critical importance of $\mathrm{Ca}^{2+}$ for signal transduction between nerve and muscle. The general theory of calcium as a universal second messenger, however, appeared half a century later, when Lewis Victor Heilbrunn concluded that "the reaction of this calcium with the protoplasm inside the cell is the most basic of all protoplasmic reactions" ${ }^{\text {[8] }}$. This theory, although almost completely ignored at the time of its appearance, brilliantly withstood the test of time and experimental efforts (Figure 1), and today, the calcium signalling is generally regarded as the most ubiquitous and the most pluripotent system, involved in regulation of almost all known cellular processes ${ }^{[9]}$.

The universality of calcium as a signaling molecule is manifested on many levels. First, $\mathrm{Ca}^{2+}$ ions act as intracellular messengers throughout phylogenetic history, from early prokaryotes to eukaryotic cells.

Second, within every cell, $\mathrm{Ca}^{2+}$ exerts its action through several very different levels, which are executed in different spatial and temporal domains. Indeed, $\mathrm{Ca}^{2+}$ ions control localized processes, (eg, exocytosis) and global responses (eg, myocyte contraction) with equivalent efficacy and ease (Figure 2). Similarly, $\mathrm{Ca}^{2+}$-dependent cellular responses occur in an amazingly wide time scale, from microseconds (eg, activation of ion channels) to many hours, weeks, months or even years (eg, synaptic plasticity, memory, long-term adaptation or neuronal ageing).

Third, the $\mathrm{Ca}^{2+}$ signaling system is constructed with an incredible intrinsic versatility. The actual molecular cascades controlling $\mathrm{Ca}^{2+}$ movements through cellular membranes (Figure 3) are limited to several families of relatively similar pumps (plasmalemmal and intracellular PMCA, SERCA or $\mathrm{SPCA}^{[10-12]}$ ), sodium-calcium exchangers (NCX, residing in plasmalemma or in mitochondria $\left.{ }^{[13,14]}\right)$ and plasmalemma ${ }^{[15-18]}$ and intracellular ${ }^{[13,19-21]} \mathrm{Ca}^{2+}$ channels. Yet these cascades are very tightly regulated, which determines their great adaptability and versatility. Importantly, calcium signalling molecules are subject to a control by $\mathrm{Ca}^{2+}$ ions themselves: changes in $\mathrm{Ca}^{2+}$ gradients or local concentration control the availability of $\mathrm{Ca}^{2+}$ channels and regulate the activity of $\mathrm{Ca}^{2+}$ pumps $^{[22-24]}$. On a different level, the expression of various molecules, controlling $\mathrm{Ca}^{2+}$ movements is responsive to the 


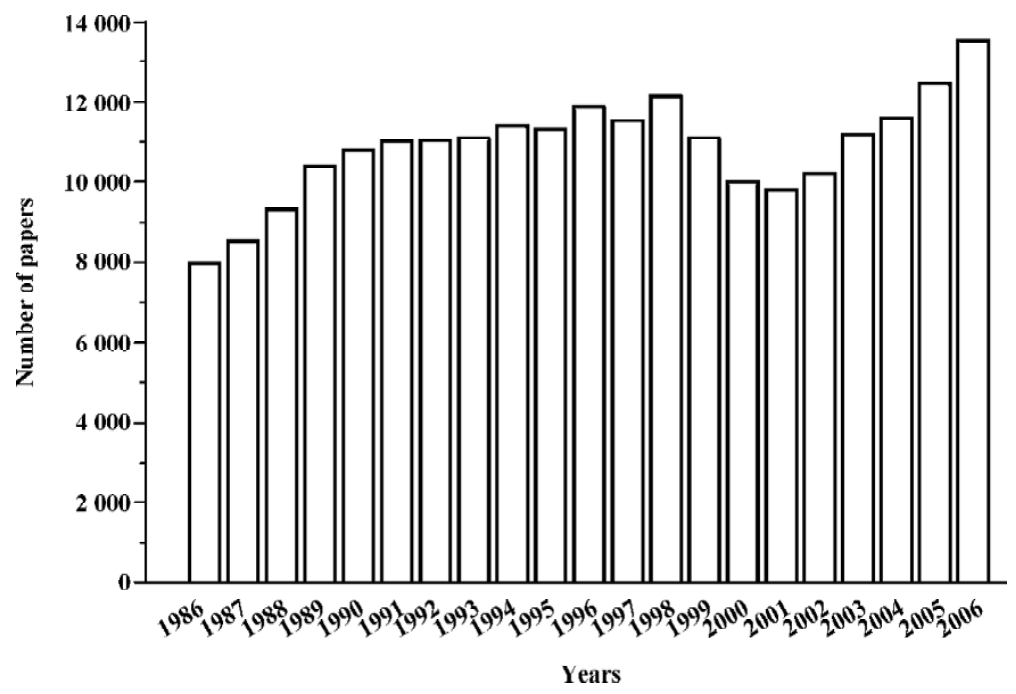

Figure 1. Publication of papers, dedicated to calcium signalling, according to the PubMed.

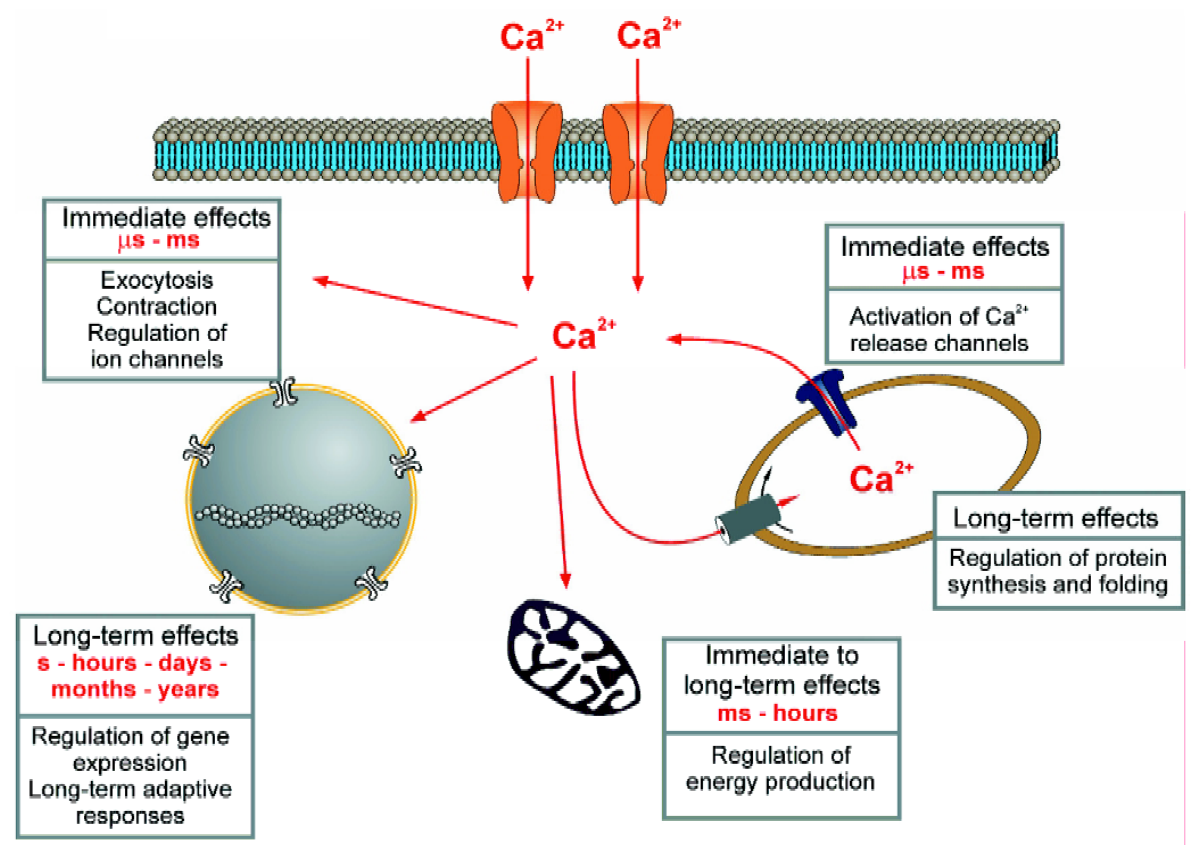

Figure 2. Temporal domains of calcium signalling.

changes in the environment, and therefore the combinations of calcium signaling molecules (or " $\mathrm{Ca}^{2+}$ signalling toolkits" ${ }^{\text {"[2] }}$ ) can be rapidly modified, thus adapting the system to the external demands.

Fourth, the effector part of the calcium signalling system, the $\mathrm{Ca}^{2+}$ sensors, is represented by thousands of proteins, which have different affinity to $\mathrm{Ca}^{2+}$ ions, with the dissociate constant spanning seven orders of magnitude (Figure 4), and different cellular location. This host of $\mathrm{Ca}^{2+}$ sensors determines the ubiquity and promiscuity of $\mathrm{Ca}^{2+}$ signaling: expression of specific $\mathrm{Ca}^{2+}$ sensors commands specific $\mathrm{Ca}^{2+}$ regulatory function (eg, expression of $\mathrm{Ca}^{2+}$-sensitive contractile in muscle cells determines the excitation contraction coupling), whereas different affinity/localization of $\mathrm{Ca}^{2+}$ sensors will allow precise regulation of very different processes within a single cell.

The specificity and precise localization of calcium signalling machinery is also supported by an existence of 


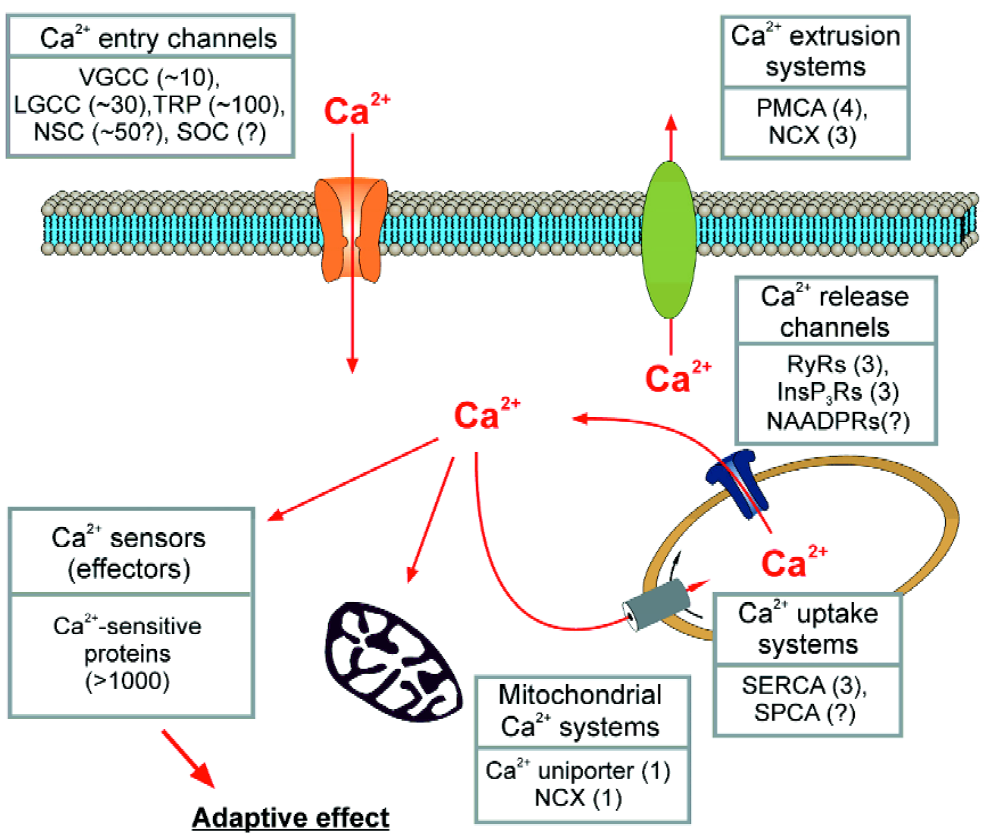

Figure 3. Simplicity and complexity of calcium signalling. Calcium signals are controlled by a relatively limited quantity of molecules (approximate number of these molecules is indicated in the parentheses), which include $\mathrm{Ca}^{2+}$ channels [voltage-gated $\mathrm{Ca}^{2+}$ channels (VGCC), ligandgated $\mathrm{Ca}^{2+}$ channels (LGCC); transient receptor potential $\mathrm{Ca}^{2+}$ permeable channels (TRP); non-selective channels; SOC-store-operated $\mathrm{Ca}^{2+}$ channels (NSC)]; plasmalemmal $\mathrm{Ca}^{2+}$ extrusion systems [plasmalemmal $\mathrm{Ca}^{2+}$ ATPase (PMCA); $\mathrm{Na}^{+} / \mathrm{Ca}^{2+}$ exchanger (NCX)); intracellular $\mathrm{Ca}^{2+}$ release channels [ryanodine receptors (RyRs); $\mathrm{InsP}_{3}$ receptors $\left(\operatorname{InsP}_{3} \mathrm{Rs}\right)$; NAADP receptors (NAADPRs)]; intracellular $\mathrm{Ca}^{2+}$ pumps [sarco(endo)plasmic reticulum $\mathrm{Ca}^{2+}$ ATPase (SERCA); $\mathrm{Ca}^{2+}$ ATPases of Golgi complex (SPCA)] and mitochondrial $\mathrm{Ca}^{2+}$ transporting systems $\left(\mathrm{Ca}^{2+}\right.$ uniporter; and mitochondrial $\mathrm{Na}^{+} / \mathrm{Ca}^{2+}$ exchanger). The calcium signalling system exerts physiological effects through $\mathrm{Ca}^{2+}$ sensors (effectors), which are represented by approximate thousands of enzymes and $\mathrm{Ca}^{2+}$-binding proteins.

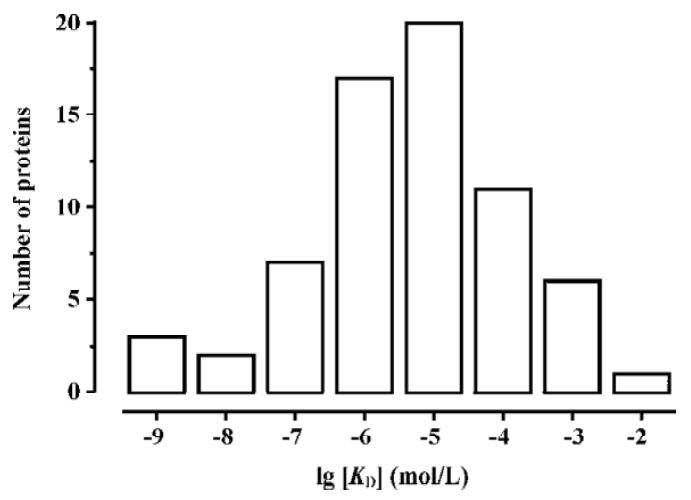

Figure 4. Diversity of calcium binding affinity of $\mathrm{Ca}^{2+}$-sensors. The dissociation constants $\left(K_{\mathrm{d}}\right)$ of $\mathrm{Ca}^{2+}$ binding proteins $\left(68 K_{\mathrm{d}}\right.$ values obtained by text search and manual curation from the literature) vary over 7 logarithmic units, ranging from $\mathrm{nmol} / \mathrm{L}$ to $10 \mathrm{mmol} / \mathrm{L}$ with a broad mode around $10 \mu \mathrm{mol} / \mathrm{L}$.

several intracellular compartments, characterized by a clearly distinct $\mathrm{Ca}^{2+}$ homeostasis. These compartments are represented by the cytosol, by endoplasmic reticulum (ER) and mitochondria. In the cytosol the concentration of free $\mathrm{Ca}^{2+}$ $\left(\left[\mathrm{Ca}^{2+}\right]_{\mathrm{i}}\right)$ is very low, approximately $50-100 \mathrm{nmol} / \mathrm{L}$, which is achieved by continuous activity of $\mathrm{Ca}^{2+}$ extruding systems and by high-affinity cytosolic calcium buffers ${ }^{[14,26,27]}$. As a consequence, activation of $\mathrm{Ca}^{2+}$ entry channels results in rapid elevation of $\left[\mathrm{Ca}^{2+}\right]_{i}$, yet the strong $\mathrm{Ca}^{2+}$ buffering favours localisation of $\mathrm{Ca}^{2+}$ signals and the creation of $\mathrm{Ca}^{2+}$ microdomains. This is very important for regulation of focal cellular responses, such as exocytosis ${ }^{[28,29]}$.

The ER, in contrast, provides for a very different $\mathrm{Ca}^{2+}$ handling environment. The intra-ER, or intraluminal free $\mathrm{Ca}^{2+}$ concentration $\left(\left[\mathrm{Ca}^{2+}\right]_{\mathrm{L}}\right)$, is set at a rather high level, 100-800 $\mu \mathrm{mol} / \mathrm{L}^{[30-36]}$, which is achieved by a continuous activity of SERCA pumps. In addition, the affinity of intra-ER $\mathrm{Ca}^{2+}$ buffers is rather low, being in the range of $0.5-1.0 \mathrm{mmol} / \mathrm{L}$, which favours $\mathrm{Ca}^{2+}$ diffusion through the continuous ER lumen. The latter therefore forms a nanoscopic " $\mathrm{Ca}^{2+}$ tunnel", which allows long-range $\mathrm{Ca}^{2+}$ transport in polarised cells ${ }^{[37-40]}$. Importantly, numerous intra-ER $\mathrm{Ca}^{2+}$-dependent enzymatic systems require high $(>50 \mu \mathrm{mol} / \mathrm{L})\left[\mathrm{Ca}^{2+}\right]_{\mathrm{L}}$ for normal functioning ${ }^{[41,42]}$. The ER acts as a very powerful intracellular signalling organelle, which integrates various incoming signals with cellular biochemistry (through regulation of protein synthesis and posttranslational folding). Furthermore, the ER produces numerous output signals, which regulate cell function and determine adaptive responses. Particularly important is the role of ER in the generation of cytoplasmic $\mathrm{Ca}^{2+}$ signals because the ER acts as a dynamic $\mathrm{Ca}^{2+}$ store able to rapidly release $\mathrm{Ca}^{2+}$ through intracellular $\mathrm{Ca}^{2+}$ channels ${ }^{[19,21]}$ and to terminate $\mathrm{Ca}^{2+}$ signals through SERCA-dependent $\mathrm{Ca}^{2+}$ pumping. As a consequence, the ER appears simultaneously as a source and sink for $\left[\mathrm{Ca}^{2+}\right]_{i}^{[43-45]}$, while the balance between $\mathrm{Ca}^{2+}$ release and $\mathrm{Ca}^{2+}$ uptake is regulated by $\left[\mathrm{Ca}^{2+}\right]_{\mathrm{L}}$ and $\left[\mathrm{Ca}^{2+}\right]_{\mathrm{i}}$ dynamics in a vicinity of $\mathrm{Ca}^{2+}$ release channels ${ }^{[46,47]}$.

The third intracellular compartment with specific $\mathrm{Ca}^{2+}$ homeostasis is represented by mitochondria, which are able 
to accumulate (via $\mathrm{Ca}^{2+}$ uniporter) and release (via $\mathrm{Na}^{+} / \mathrm{Ca}^{2+}$ exchanger) $\mathrm{Ca}^{2+[13]}$. Mitochondrial $\mathrm{Ca}^{2+}$ signalling links cellular activity to ATP production and ROS metabolism; in addition mitochondria can participate in $\left[\mathrm{Ca}^{2+}\right]_{\mathrm{i}}$ regulation, especially in pathological conditions ${ }^{[48-50]}$.

Finally, the signalling system mediated by $\mathrm{Ca}^{2+}$ ions operates in two modes: the digital and analogue. The digital mode is determined by a discrete character of $\mathrm{Ca}^{2+}$ entry through the membrane, which is controlled by opening and closing of $\mathrm{Ca}^{2+}$ permeable channels. Yet, when inside the intracellular compartments, $\mathrm{Ca}^{2+}$ ions diffuse, and they diffuse with a different velocity and anisotropy, thus creating a complex concentration gradients, which represents an analogue signalling, coded in amplitude, space and time.

All these features make the $\mathrm{Ca}^{2+}$ signaling system absolutely unique among other cellular signaling pathways. $\mathrm{Ca}^{2+}$ ions are fundamentally different from other signalling molecules in a sense that they are subjected to neither catabolism nor anabolism; they can be merely bound to calcium buffers or accumulated into $\mathrm{Ca}^{2+}$ stores, yet they remain readily available for mobilisation. This makes the signalling system quite economical. Huge $\mathrm{Ca}^{2+}$ gradients, existing between extracellular space, intracellular organelles and the cytoplasm contribute to an exceedingly high signal-to-noise ratio of the whole signalling system. Further, the promiscuity of $\mathrm{Ca}^{2+}$ ions as intracellular messengers provides for a remarkable versatility; the variety of $\mathrm{Ca}^{2+}$ sensor proteins together with temporal and spatial heterogeneity of $\mathrm{Ca}^{2+}$ fluctuations, make the signalling system both context and history-specific. As a consequence, $\mathrm{Ca}^{2+}$ ions often play very opposite effects even within the same cell. One of the best examples of such a dualism exists in arterial smooth muscle cells, where subsurface calcium sparks relax the myocyte by activating $\mathrm{Ca}^{2+}$-dependent $\mathrm{K}^{+}$channels ${ }^{[51-53]}$, whereas global calcium signals trigger cell contraction.

Not surprisingly, the omnipotence of $\mathrm{Ca}^{2+}$ signaling makes it an important player not only in normal conditions but also in pathological cellular reactions. Here the dualism of $\mathrm{Ca}^{2+}$ ions transpires even more illustriously, as indeed $\mathrm{Ca}^{2+}$ ions are the ions of life and death. Depriving the cells from $\mathrm{Ca}^{2+}$ ions by the removal of extracellular $\mathrm{Ca}^{2+}$, or artificial chelating of intracellular $\mathrm{Ca}^{2+}$, or depletion of cellular free $\mathrm{Ca}^{2+}$, all of these interventions result in rapid and inevitable cell death ${ }^{[2,54]}$. At the same time excess of $\mathrm{Ca}^{2+}$ is absolutely toxic, and cell death from $\mathrm{Ca}^{2+}$ overload represents probably the most general mechanism of cell demise ${ }^{[55,56]}$. Similarly, chronic disruptions of $\mathrm{Ca}^{2+}$ homeostatic machinery may cause development of various diseases, such as ischemic-induced cell death ${ }^{[57-63]}$, neurodegeneration ${ }^{[42,54,64]}$, heart failure ${ }^{[65,66]}$ or underlying cognitive deficits in senescence $^{[67-69]}$

When compiling this special issue we tried to cover all of the important parts of calcium signaling machinery and its role in physiology and disease. We hope that this collection of articles will spark further interest in various aspects of $\mathrm{Ca}^{2+}$ and inspire further developments into the functions and importance of this truly magnificent ion of life.

\section{References}

1 Ringer S. A further contribution regarding the influence of different constituents of the blood on the contractions of the heart. J Physiol (Lond) 1883; 4: 29-43.

2 Ringer S. The influence of saline media on fishes. J Physiol (Lond) 1883; 4: vi-viii.

3 Ringer S. Further experiments regarding the influence of small quantities of lime, potassium and other salts on muscular tissue. $\mathrm{J}$ Physiol (Lond) 1886; 7 : 291-308.

4 Ringer S. Concerning experiments to test the influence of lime, sodium and potassium salts on the development of ova and growth of tadpoles. J Physiol (Lond) 1890; 11: 79-84.

5 Ringer S Sainsbury H. The action of potassium, sodium and calcium salts on Tubifex rivulorum. J Physiol (Lond) 1894; 16: $1-9$.

6 Locke FS. Notiz uber den Einfluss, physiologisher Kochsalzlosung auf die Eregbarkeit von Muscel and Nerve. Zentralb Physiol 1894; 8: 166-7.

7 Overton E. Beitrage zur allgemeinen Muskel- und Nerven physiologie. III. Mittheilung. Studien uber die Wirkung der Alkali-und Erdkali-salze auf Skeletalmuskeln und Nerven. Pflugers Arch 1904; 105: 176-290.

8 Heilbrunn LV. An outline of general physiology. Philadelphia: Saunders; 1943

9 Petersen $\mathrm{OH}$, Michalak M, Verkhratsky A. Calcium signalling: past, present and future. Cell Calcium 2005; 38: 161-9.

10 Wuytack F, Raeymaekers L Missiaen L. PMR1/SPCA Ca ${ }^{2+}$ pumps and the role of the Golgi apparatus as a $\mathrm{Ca}^{2+}$ store. Pflugers Arch 2003; 446: 148-53.

11 Vanoevelen J, Dode L, Van Baelen K, Fairclough RJ, Missiaen L, Raeymaekers L, et al. The secretory pathway $\mathrm{Ca}^{2+} / \mathrm{Mn}^{2+}-\mathrm{AT}$ Pase 2 is a Golgi-localized pump with high affinity for $\mathrm{Ca}^{2+}$ ions. J Biol Chem 2005; 280: 22800-8.

12 Vangheluwe P, Raeymaekers L, Dode L, Wuytack F. Modulating sarco(endo)plasmic reticulum $\mathrm{Ca}^{2+}$ ATPase 2 (SERCA2) activity: cell biological implications. Cell Calcium 2005; 38: 291-302.

13 Nicholls DG. Mitochondria and calcium signaling. Cell Calcium 2005; 38: 311-7.

14 Guerini D, Coletto L, Carafoli E. Exporting calcium from cells. Cell Calcium 2005; 38: 281-9.

15 Triggle DJ. L-type calcium channels. Curr Pharm Des 2006; 12: 443-57.

16 Parekh AB, Putney JW Jr. Store-operated calcium channels. Physiol Rev 2005; 85: 757-810.

17 Perez-Reyes E. Molecular physiology of low-voltage-activated t-type calcium channels. Physiol Rev 2003; 83: 117-61.

18 Pedersen SF, Owsianik G Nilius B. TRP channels: an overview. 
Cell Calcium 2005; 38: 233-52.

19 Bezprozvanny I. The inositol 1,4,5-trisphosphate receptors. Cell Calcium 2005; 38: 261-72.

20 Galione A, Ruas M. NAADP receptors. Cell Calcium 2005; 38 : 273-80.

21 Hamilton SL. Ryanodine receptors. Cell Calcium 2005; 38 : 253-60.

22 Morad M, Soldatov N. Calcium channel inactivation: possible role in signal transduction and $\mathrm{Ca}^{2+}$ signaling. Cell Calcium 2005; 38: 223-31.

23 Burdakov D, Verkhratsky A. Biophysical re-equilibration of $\mathrm{Ca}^{2+}$ fluxes as a simple biologically plausible explanation for complex intracellular $\mathrm{Ca}^{2+}$ release patterns. FEBS Lett 2006; 380: 463-8.

24 Burdakov D, Petersen $\mathrm{OH}$, Verkhratsky A. Intraluminal calcium as a primary regulator of endoplasmic reticulum function. Cell Calcium 2005; 38: 303-10.

25 Berridge MJ, Bootman MD, Roderick HL. Calcium signalling: dynamics, homeostasis and remodelling. Nat Rev Mol Cell Biol 2003; 4: 517-29.

26 Petersen $\mathrm{OH}$, Petersen $\mathrm{CC}$, Kasai H. Calcium and hormone action. Annu Rev Physiol 1994; 56: 297-319.

27 Burnashev N, Rozov A. Presynaptic $\mathrm{Ca}^{2+}$ dynamics, $\mathrm{Ca}^{2+}$ buffers and synaptic efficacy. Cell Calcium 2005; 37: 489-95.

28 Barclay JW, Morgan A, Burgoyne RD. Calcium-dependent regulation of exocytosis. Cell Calcium 2005; 38: 343-53.

29 Jarvis SE, Zamponi GW. Masters or slaves? Vesicle release machinery and the regulation of presynaptic calcium channels. Cell Calcium 2005; 37: 483-8.

30 Alonso MT, Barrero MJ, Michelena P, Carnicero E, Cuchillo I, Garcia AG, et al. $\mathrm{Ca}^{2+}$-induced $\mathrm{Ca}^{2+}$ release in chromaffin cells seen from inside the ER with targeted aequorin. J Cell Biol 1999; 144: 241-54.

31 Alvarez J, Montero M. Measuring $\left[\mathrm{Ca}^{2+}\right]$ in the endoplasmic reticulum with aequorin. Cell Calcium 2002; 32: 251-60.

32 Mogami H, Tepikin AV, Petersen $\mathrm{OH}$. Termination of cytosolic $\mathrm{Ca}^{2+}$ signals: $\mathrm{Ca}^{2+}$ reuptake into intracellular stores is regulated by the free $\mathrm{Ca}^{2+}$ concentration in the store lumen. EMBO J 1998; 17: 435-42.

33 Solovyova N, Verkhratsky A. Neuronal endoplasmic reticulum acts as a single functional $\mathrm{Ca}^{2+}$ store shared by ryanodine and inositol-1,4,5-trisphosphate receptors as revealed by intra-ER $\left[\mathrm{Ca}^{2+}\right]$ recordings in single rat sensory neurones. Pflugers Arch 2003; 446: 447-54.

34 Solovyova N, Veselovsky N, Toescu EC, Verkhratsky A. $\mathrm{Ca}^{2+}$ dynamics in the lumen of the endoplasmic reticulum in sensory neurons: direct visualization of $\mathrm{Ca}^{2+}$-induced $\mathrm{Ca}^{2+}$ release triggered by physiological $\mathrm{Ca}^{2+}$ entry. EMBO J 2002; 21: 622-30.

35 Tse FW, Tse A, Hille B. Cyclic $\mathrm{Ca}^{2+}$ changes in intracellular stores of gonadotropes during gonadotropin-releasing hormonestimulated $\mathrm{Ca}^{2+}$ oscillations. Proc Natl Acad Sci USA 1994; 91 : $9750-4$.

36 Verkhratsky A. Physiology and pathophysiology of the calcium store in the endoplasmic reticulum of neurons. Physiol Rev 2005; 85: 201-79.

37 Mogami H, Nakano K, Tepikin AV, Petersen OH. $\mathrm{Ca}^{2+}$ flow via tunnels in polarized cells: recharging of apical $\mathrm{Ca}^{2+}$ stores by focal $\mathrm{Ca}^{2+}$ entry through basal membrane patch. Cell 1997; 88: 49-55.
38 Mogami H, Gardner J, Gerasimenko OV, Camello P, Petersen $\mathrm{OH}$, Tepikin AV. Calcium binding capacity of the cytosol and endoplasmic reticulum of mouse pancreatic acinar cells. J Physiol 1999; 518: 463-7.

39 Petersen $\mathrm{OH}$, Tepikin A, Park MK. The endoplasmic reticulum: one continuous or several separate $\mathrm{Ca}^{2+}$ stores? Trends Neurosci 2001; 24: 271-6.

40 Verkhratsky A. The endoplasmic reticulum and neuronal calcium signalling. Cell Calcium 2002; 32: 393-404.

41 Michalak M, Robert Parker JM, Opas M. $\mathrm{Ca}^{2+}$ signaling and calcium binding chaperones of the endoplasmic reticulum. Cell Calcium 2002; 32: 269-78.

42 Verkhratsky A, Toescu EC. Endoplasmic reticulum $\mathrm{Ca}^{2+}$ homeostasis and neuronal death. J Cell Mol Med 2003; 7: 351-61.

43 Friel DD, Tsien RW. A caffeine- and ryanodine-sensitive $\mathrm{Ca}^{2+}$ store in bullfrog sympathetic neurones modulates effects of $\mathrm{Ca}^{2+}$ entry on $\left[\mathrm{Ca}^{2+}\right]_{\mathrm{i}}$. J Physiol 1992; 450: 217-46.

44 Shmigol A, Kostyuk P, Verkhratsky A. Role of caffeine-sensitive $\mathrm{Ca}^{2+}$ stores in $\mathrm{Ca}^{2+}$ signal termination in adult mouse DRG neurones. Neuroreport 1994; 5: 2073-6.

45 Usachev Y, Shmigol A, Pronchuk N, Kostyuk P, Verkhratsky A. Caffeine-induced calcium release from internal stores in cultured rat sensory neurons. Neuroscience 1993; 57: 845-59.

46 Hongpaisan J, Pivovarova NB, Colegrove SL, Leapman RD, Friel DD, Andrews SB. Multiple modes of calcium-induced calcium release in sympathetic neurons II: a $\left[\mathrm{Ca}^{2+}\right]$ )- and location-dependent transition from endoplasmic reticulum $\mathrm{Ca}$ accumulation to net Ca release. J Gen Physiol 2001; 118: 101-12.

47 Albrecht MA, Colegrove SL, Hongpaisan J, Pivovarova NB, Andrews SB, Friel DD. Multiple modes of calcium-induced calcium release in sympathetic neurons I: attenuation of endoplasmic reticulum $\mathrm{Ca}^{2+}$ accumulation at low $\left[\mathrm{Ca}^{2+}\right]_{\mathrm{i}}$ during weak depolarization. J Gen Physiol 2001; 118: 83-100.

48 Toescu EC, Verkhratsky A. Neuronal ageing from an intraneuronal perspective: roles of endoplasmic reticulum and mitochondria. Cell Calcium 2003; 34: 311-23.

49 Toescu EC. Hypoxia sensing and pathways of cytosolic $\mathrm{Ca}^{2+}$ increases. Cell Calcium 2004; 36: 187-99.

50 Toescu EC. Hypoxia response elements. Cell Calcium 2004; 36 : 181-5.

51 Nelson MT, Cheng H, Rubart M, Santana LF, Bonev AD, Knot $\mathrm{HJ}$, et al. Relaxation of arterial smooth muscle by calcium sparks. Science 1995; 270: 633-7.

52 Wellman GC, Nathan DJ, Saundry CM, Perez G, Bonev AD, Penar $\mathrm{PL}$, et al. $\mathrm{Ca}^{2+}$ sparks and their function in human cerebral arteries. Stroke 2002; 33: 802-8.

53 Wellman GC, Nelson MT. Signaling between SR and plasmalemma in smooth muscle: sparks and the activation of $\mathrm{Ca}^{2+}$-sensitive ion channels. Cell Calcium 2003; 34: 211-29.

54 Paschen W, Mengesdorf T. Endoplasmic reticulum stress response and neurodegeneration. Cell Calcium 2005; 38: 409-15.

55 Berliocchi L, Bano D, Nicotera P. $\mathrm{Ca}^{2+}$ signals and death programmes in neurons. Philos Trans R Soc Lond B Biol Sci 2005; 360: 2255-8.

56 Leist M, Nicotera P. Apoptosis versus necrosis: the shape of neuronal cell death. Results Probl Cell Differ 1998; 24: 105-35.

57 Kristian T. Metabolic stages, mitochondria and calcium in hypoxic/ischemic brain damage. Cell Calcium 2004; 36: 221-33. 
58 Pringle AK. In, out, shake it all about: elevation of $\left[\mathrm{Ca}^{2+}\right]_{\mathrm{i}}$ during acute cerebral ischaemia. Cell Calcium 2004; 36: 235-45.

59 Yao H, Haddad GG. Calcium and $\mathrm{pH}$ homeostasis in neurons during hypoxia and ischemia. Cell Calcium 2004; 36: 247-55.

60 Starkov AA, Chinopoulos C, Fiskum G. Mitochondrial calcium and oxidative stress as mediators of ischemic brain injury. Cell Calcium 2004; 36: 257-64.

61 Pisani A, Bonsi P, Calabresi P. Calcium signaling and neuronal vulnerability to ischemia in the striatum. Cell Calcium 2004; 36 : 277-84.

62 Yamashima T. $\mathrm{Ca}^{2+}$-dependent proteases in ischemic neuronal death: a conserved 'calpain-cathepsin cascade' from nematodes to primates. Cell Calcium 2004; 36: 285-93.

63 Kahlert S, Reiser G. Glial perspectives of metabolic states during cerebral hypoxia-calcium regulation and metabolic energy. Cell Calcium 2004; 36: 295-302.
64 Mattson MP, Chan SL. Neuronal and glial calcium signaling in Alzheimer's disease. Cell Calcium 2003; 34: 385-97.

65 Scoote M, Williams AJ. Myocardial calcium signalling and arrhythmia pathogenesis. Biochem Biophys Res Commun 2004; 322: 1286-309.

66 Sipido KR, Eisner D. Something old, something new: changing views on the cellular mechanisms of heart failure. Cardiovasc Res 2005; 68: 167-74.

67 Toescu EC, Verkhratsky A. $\mathrm{Ca}^{2+}$ and mitochondria as substrates for deficits in synaptic plasticity in normal brain ageing. J Cell Mol Med 2004; 8: 181-90.

68 Verkhratsky A, Toescu EC. Calcium and neuronal ageing. Trends Neurosci 1998; 21: 2-7.

69 Toescu EC, Verkhratsky A, Landfield PW. $\mathrm{Ca}^{2+}$ regulation and gene expression in normal brain aging. Trends Neurosci 2004; 27: 614-20.

\title{
The 7th Chinese Symposium on Calcium Signalling (The 7th CSCS Meeting)
}

\author{
October/November 2008, Wuhan, China
}

Info: Prof Zong-jie CUI, PhD

Institute of Cell Biology

Beijing Normal University

Beijing 100875, China

Phn/Fax 86-10-5880-9162

E-mail zjcui@bnu.edu.cn 